\title{
Where will Benedict XVI lead his sheep?
}

\author{
Martha Campbell and Malcolm Potts
}

Since the Second Vatican Council (1962-1965), a majority of theologians and the vast majority of the laity have accepted sexual intercourse as an intrinsic part of a loving relationship. However, the white puff of smoke coming from the Sistine Chapel signifying the election of Pope Benedict XVI will turn into a black cloud for reproductive freedom for a billion Catholics. In the short term it may also hurt non-Catholics, as the new Pope's stand on these basic human issues may encourage other fundamentalists to impose new constraints.

When Pope John XXIII was inspired to launch the Second Vatican Council in $1959,{ }^{1}$ he let the light of reason and science into discussions of human sexuality. Great numbers of thinking Catholics began to question the tradition that virginity was the God-given ideal and that the only justification for sex was procreation. Some went further and argued that priests need not be celibate.

As Cardinal Ratzinger, Pope Benedict XVI was a chief adviser to Pope John Paul II and head of the Sacred Congregation for the Doctrine of the Faith. This is the department in charge of defining Roman Catholic orthodoxy, which grew out of the Inquisition. In a letter about AIDS to an Archbishop in 1988, he described a recent 'clarification' of policy: "To seek a solution to the problem of infection by promoting the use of prophylactics would be to embark on a way not only insufficiently reliable from the technical point of view, but also and above all, unacceptable from the moral aspect". 2

For John Paul II, the well-being of women was not a high priority, as he was impervious to the sad consequences of Rome's continued proscription against fertility regulation methods. He also turned a deaf ear to the news that thousands of young boys had been used sexually by Catholic priests. With his continuing ban on condoms he was responsible for millions of deaths from AIDS in Africa and other regions of the world. Catholic hospitals throughout the USA ban contraceptive advice and services, refuse to give emergency contraception to rape victims, and abortion is unthinkable. ${ }^{3}$ Such hospitals account for nearly $20 \%$ of hospital beds in the USA and are often the only local source of health care.

John Rock, the Boston obstetrician who led the clinical development of the Pill, was a devout Catholic who attended Mass every morning. ${ }^{4}$ In 1963, in The Time Has Come ${ }^{5}$ he argued that the Pill was a licit method of contraception for Catholics because it imitated the natural suppression of ovulation during pregnancy and lactation. Many in the Church went along with him, and the Vatican established a Pontifical Commission to discuss contraception. The Commission voted to reverse the longstanding condemnation of contraception, but in 1968 Pope Paul VI overruled their findings in the encyclical Humanae vitae. As one theologian put it, “... if the church sent all those souls to hell [for practising contraception], it must keep maintaining that that is where they are". ${ }^{6}$

J Fam Plann Reprod Health Care 2005; 31(3): 175-177

School of Public Health, University of California, Berkeley, CA, USA

Martha M Campbell, PhD, Lecturer

Malcolm Potts, PhD, FRCOG, Bixby Professor

Correspondence to: Dr Martha M Campbell, School of Public Health, 310 Warren Hall, University of California, Berkeley, CA 94720-7360, USA. E-mail: mcbell@berkeley.edu
Humanae vitae tore the Church apart, and shocked theologians such as Bernard Haring, Charles Curran and Francis Xavier Murphy who had welcomed Vatican II. John Rock and millions of others stopped going to Mass. Pope Paul's mistake was to reaffirm St Augustine's teaching, identifying sex with sin. Augustine taught that newborn children were infected with Original Sin and would burn eternally in Hell unless protected by the sacrament of baptism. The infection, according to Augustine, had been passed down through the generations since Adam, like some latter-day virus. Whilst Vatican II recognised that sex could express love as well as procreation, Humanae vitae stated: "Similarly excluded [as a lawful means for controlling the birth of a child] is any action, which is either before, at the moment of, or after sexual intercourse, is specifically intended to prevent procreation as an end or a means".

John Paul and now Benedict XVI have continued Augustine's conservative, 1500-year-old interpretation of human reproduction. Augustine himself had lived with a mistress, who bore him a son, for many years and then abandoned them both when he converted to Christianity. He was honest enough to admit that he had never met a married man who had intercourse "solely in the hope of conception", yet by misinterpreting human sexuality, he built an intellectual prison from which the only escape was to teach that the sole justification for sex was to conceive a child. Celibacy automatically became superior to marriage and instead of ennobling human love it degraded women.

The Church's doctrine of subjugation of women has had appalling consequences. For example, towards the end of John Paul's papacy, the Church received a report detailing nuns made pregnant by priests, and then encouraging them to have abortions. ${ }^{7}$ Had John XXIII lived, the Church might have followed a more humane, evidence-based interpretation of human sexuality. As it is, John Paul and Ratzinger, as his chief adviser, reinforced a millennium and a half of hostility towards women. Although many are praying for a genuine miracle, it is unlikely that Ratzinger, now 78 years old, will alter his deepest beliefs on his elevation to the Papacy.

It is unfair to criticise the adolescent Ratzinger for joining the Hitler Youth, but it is relevant to remember how the Church's deep hostility to sex helped mislead the 1933 Bishop's Conference in Germany into expressing "gratitude to Hitler" for suppressing "immorality". The German church had been particularly offended by Ideal Marriage, ${ }^{8}$ written by the Dutch gynaecologist, Theodor Henrick van de Velde.

For Catholics, Pope Benedict XVI will continue to stimulate ambivalence towards contraception in the West and actively obstruct family planning choices in countries such as the Philippines. Poor access and irregular use of contraception are one reason why, in the same societies, Catholics sometimes have more induced abortions than their protestant neighbours. 9 There is estimated to be 400000 abortions a year in the Philippines.

Some $69 \%$ of North Americans believe that 'There is a personal God', while in the UK less than half that number (33\%) share the same belief. ${ }^{10}$ Pope Benedict condemns 'relativism', by which he means that there is only one correct religion. By this logic, protestants are not adhering to the true Church, but no doubt Christian fundamentalists in the USA will still welcome the new Pope as a political 
ally in their assault on family planning. It is almost certain that President Bush will nominate a conservative to replace Chief Justice Renquist when he leaves the Supreme Court. The US Food and Drug Administration could be forced to withdraw approval of mifepristone, and the expert advice to switch emergency contraception to over-the-counter status may continue to be vetoed. Internationally, the hostility of the Bush administration to women and family planning is likely to accelerate. Currently they are pressurising the director of the World Health Organization not to permit misoprostol (which has the potential to save the lives of scores of thousands of women from dying of postpartum haemorrhage) to be added to the essential drugs list. ${ }^{11}$

No one will deny Benedict's sincerity, any more than they could that of John Paul II, but a misinformed body of knowledge combined with great power is not only a human tragedy; in this case it will lead to a great deal of emotional and physical pain, and millions of additional deaths. As the enforcer of pure doctrine, he has forced the resignation of the Rev. Thomas J Reese, editor of the Catholic magazine America, which is a thoughtful journal exploring more than one perspective on Catholic thought. ${ }^{12}$ This act echoes the crackdown on the press by Russia's Vladamir Putin, and that of the fascists in the 1930s.

Is there any possible silver lining to be found in the election of a rigid enforcer of conservative doctrine? It may be that under Pope Benedict XVI the Church will overreach itself in trying to enforce its orthodoxies against prevailing social trends, and thereby undermine itself. If a more liberal Pope had been elected, he might have sanctioned contraception but condemned abortion, adding to the pressure to roll back access to safe abortion. A conservative Pope is likely to alienate the majority of the laity on all fronts and perhaps damage the authority of Rome even more than Humanae vitae. Already $70 \%$ of women in Brazil are using artificial contraception, and little respect is shown for the church's reproductive rules contributing to the growth of Protestant, pentacostal churches in Latin America. ${ }^{13}$ But this change through disobedience to the Vatican, creating de facto liberalisation and improved women's health for the rich before the poor, will roll out only slowly through lack of authority, instead of a change of doctrine which would save lives and show the kind of humanity many of us would prefer to see offered from houses of religion.

Statements on funding and competing interests

Funding. None identified.

Competing interests. None identified.

References

1 Rynne X (aka Murphy FX). Vatican Council II. Maryknoll, NY: Orbis Books, 1996.

2 "Prevention of AIDS: Christian ethical aspect" in L'Osservatore Romano, 10 March 1988, quote in letter of Joseph Cardinal Ratzinger. 29 May 1988.

3 Rodriguea P, Shields WC. Religion and medicine. Contraception 1995; 71: 302-303.

4 Asbell B. The Pill: A Biography of the Drug that Changed the World. New York, NY: Random House, 1995

5 Rock J. The Time had Come: A Catholic Doctor's Proposals to End the Battle over Birth Control. London, UK: Longman, 1995.

6 Wills G. Papal Sin: Structures of Deceit. New York, NY: Doubleday, 2000; 94.

7 Allen J, Schaeffer P. Reports of abuse: AIDS exacerbates sexual exploitation of nuns, reports allege. National Catholic Reporter, 16 March 2001. http://www.natcath.com/NCR_Online/archives/031601/ 031601a.htm [Accessed 10 May 2005].

8 van de Velde TH. Ideal Marriage. London, UK: Heinemann, 1928.

9 Potts M, Diggory P, Peel J. Abortion. Cambridge, UK: Cambridge University Press, 1977; 120

10 Inglehart R, Basanez M, Moreno A. Human Values and Beliefs: A Cross-Cultural Sourcebook: Political, Religious, Sexual and Economic Norms in 43 Societies: Findings from the 1990-1993 World Values Survey. Ann Arbor, MI: University of Michigan Press, 1998.

11 Boseley S. US accused of trying to block abortion pills. The Guardian, 21 April 2005.

12 Goodstein L. Vatican is said to force Jesuit off magazine. New York Times, 7 May 2005; 1.

13 Kristof N. Catholic devotion, and doubts. New York Times (Commentary), 10 May 2005; A21.

\section{HOW TO REGISTER FOR ACCESS TO THE ELECTRONIC JOURNAL}

\section{Registration Process}

1. On connecting with the Faculty website (www.ffprhc.org.uk), click on the picture of the 'Journal' to access the electronic Journal.

2. Next, under Related Links, click on 'Faculty Membership Activation'.

3. In the appropriate boxes enter your Surname, E-mail Address, Country and Membership Number (M000, D000, etc - six digits). NB. These boxes are case-sensitive.

4. Next, select a User Name and Password.

5. Ignore the box marked 'Ingenta Select ID number - CID'.

6. Click on 'Enable Access'.

7. A confirmation e-mail will be sent to you.

\section{After Registration}

Once you have registered you can access the Journal as follows:

1. On connecting with the Faculty website (www.ffprhc.org.uk), click on the picture of the 'Journal' to access the electronic Journal.

2. Select the volume and issue number.

3. Select the article you wish to view.

4. Enter your user name and password. 